\title{
Factors motivating buying behavior of female two wheeler users in the district of Palghar
}

\author{
Anil Jain ${ }^{1}$, Nirmala Joshi ${ }^{2}$, Anand J Mayee ${ }^{3 *}$ \\ ${ }^{1} \mathrm{Ph} . \mathrm{D}$. Guide, ${ }^{2}$ Professor, Research Head, ${ }^{3} \mathrm{PhD}$ Scholar, ${ }^{1,3} \mathrm{Pacific}$ Academy of Higher Education \& Research University, Udaipur, \\ Rajasthan, India, ${ }^{2}$ Institute of Management -Mumbai Education Trust, Mumbai, Maharashtra, India
}

*Corresponding Author: Anand J Mayee

Email: ajmayee@gmail.com

\begin{abstract}
Covid-19 has impacted all industries globally in a big way. The Indian two wheeler industry is no exception. The Indian two wheeler Industry is considered to be one of the biggest industries of the world, which contributes significantly to the economic growth of the country. Indian automobile market is one of the most competitive one, with many big players into the fray. The number of two wheeler users is increasing every year, especially with more and more women now owning a two wheeler. Majority of the two wheeler owners reside in rural India. The world is changing very rapidly, but the world of women folk is changing faster. Traditionally the women still continue to manage the house, but now are also venturing out of their homes to seek higher education and make a successful career. Understanding the perception of females towards brands remains a complex, but a topic of strong interest for researchers. The study was undertaken to assess the factors considered to be important by women when choosing to buy a two wheeler in the district of Palghar. The sample considered for research was 150 respondents. The data required for the study has been collected through questionnaire and has been analyzed through statistical techniques and tools such as simple percentage, and Chi Square test.
\end{abstract}

Keywords: Automobile, Brand, Two wheeler, Perception, Industry.

\section{Introduction}

The frequent lockdowns, loss of jobs and income has impacted the automobile sector. The approach of the consumers and the marketers is wait and watch. The Indian two wheeler industry is perhaps next only to the Mobile and $\mathrm{T} . \mathrm{V}$ producing factories, where new models are launched, and products are upgraded, innovative marketing strategies are used, and have celebrities endorsing the products. The expectations of the consumers are increasing and they are now more demanding. Most men and women, who can afford a four wheeler, still opt for a two wheeler as they find it more convenient for travelling. Women today are not only mentally powered but also economically powered. They have their own expectations and desires, which naturally would be different from their male counter parts. They no longer like to depend on any one for their mobility. They aspire to be independent. Owning a two wheeler, gives them the freedom of travelling on their own free will. Also rise in educational levels has only increased the awareness of women. Brand awareness and knowledge of brands, a few decades ago was only limited to the male domain, but now women have their own opinions about brands and express them openly and confidently. The biggest advantage of choosing a scooter is that, scooter is comparatively easier to travel, easy to operate, and convenient to park anywhere. Scooters / mopeds are easy to ride as most Indians have learned to ride a cycle as young kids, thus learning to ride a scooter or moped is simply upgrading oneself. The number of female two wheeler users continues to increase every year, with more and more females going for higher education and increasing number of women taking up jobs. A two wheeler reduces dependence on the public transport and possessing a two wheeler for self gives the owner independence in travelling.

\section{Review of Literature}

1. Dr. R. Gopi and A. Angel in their research paper "women's preference towards scooters in Udumalpet" state that women in Udumalpet prefer owning a scooter for their mobility. A number of factors like age, occupation, members in the family, family income etc. have an impact on the buying behavior. Style, acceleration, riding comfort and price were important features which attracted the consumers. Riding comfort was ranked as the most important factor, followed by style, price and acceleration respectively.

2. V. Athulya \& Dr. M. Ramya, in their work tilted "A Study on Women's Preference towards Two Wheeler Brands with Special Reference to Calicut City" explains that women own a two wheeler for their own convenience. Factors like product attributes, price, credit facility and brand had a major impact on the buying behavior. Suzuki Access is the leading brand in Calicut city, followed by Honda and Vespa. The study concluded that women possess a two wheeler for their own convenience.

3. A. Anandalakshmy \& Dr. K. Brindha, Women's Preference of Two Wheelers with Special Reference to Coimbatore Citystate consumer's expectations and satisfaction are fulfilled when they are supplied with superior quality products at affordable prices. Consumers preferances to a large extent depends on the brand. Factors like mileage, resale value, easy to operate, cheap spares and loan / installment facility have an impact on buying behavior.

4. Dr. M. Sakthivel Murugan and R.M. Shanthi "Perception of Women Consumers towards the Purchase Decision of Two Wheelers in India - A Study with Reference to Metropolitan Cities" state that regions have a strong influence on the preferences on 
the consumers. Product performance tends to have major influence on the women consumers. Attitude, promotional schemes and utilitarian benefits have an important role.

5. Balakrishna Swarna and Dr. Krishna Banana "A Study on Customer Satisfaction Level of Two wheeler Users in Prakasam (dt), Andhra Pradesh" state that satisfaction level for Bajaj two wheeler was quite high, followed by other brands. Female two wheeler user's satisfaction level was higher as compared to males for the brands owned.

6. Dr. V. Rana Pratap "Consumers Perception towards Two-Wheelers - A Study of Suzuki Access Motor Cycle in Warangal, Telangana" illustrate that most buyers go to the company showroom to get the required information. Mileage, Engine capacity, safety, price and availability of spare parts are major factors which influence consumers. Resale value, brand name and aftersales service facilities assume lower level of significance.

7. K. P Najeemudeen, and N. Panchanatham "Information Sources for Two-wheeler Purchase: An Analytical Study with Special Focus on Malappuram District of Kerala" emphasize that modern day consumers are very shrewd and rational. They access information through the use of technology. Customers don't get influenced by T.V commercials but are more concerned by quality and performance of the product. According to the study users of the product are the best brand ambassadors for the product as new buyers usually consult them before making their decisions. Self-boasting T.V commercials endorsed by celebrities do not have much of an impact on the consumers mind any more.

8. Dr. V Devaki Nandini in the research work titled "A study on customer preference towards two wheelers in Coimbatore city" highlighted that, most persons use two wheelers for travelling to office and the trips are less than 20 miles, this creates a huge market opportunity for e-bikes. The paper also suggests that considering the economic aspects, most will prefer a two wheeler compared to a four wheeler.

\section{Objectives of the Study}

1. To understand the various factors, that motivate women buy a two wheeler.

2. To evaluate various factors that have an impact on buying behavior.

3. To suggest measures to increase satisfaction level of the female consumers.

\section{Research Methodology}

The study was conducted through the use of primary and secondary data. Random sampling has been used for the collection of primary data. Secondary data has been collected exclusively through the use of websites, journals, research articles and news reports. Primary data has been collected through the use of structured questionnaires. A sample size of 150 respondents was considered for the study. The study was limited only to the district of Palghar distant suburb of Mumbai city.

\section{Hypothesis}

The study is undertaken with the following hypotheses-

1. $\mathrm{Ho}=$ There is no difference in motives/ preferences to buy a two wheeler by women riders.

2. $\mathrm{Ha}=$ There is difference in preferences to buy a two wheeler by women riders.

3. Ho= Buying decision is independent of celebrity endorsement on women residing in Palghar district

4. $\mathrm{Ha}=$ Buying decision is not independent of celebrity endorsement on women residing in Palghar district.

\section{Data Analysis}

Various statistical tools have been used for analysis of the primary data. Microsoft excel has been used for making tables, charts and graphs. The data collected has been analysed using tests like simple percentage method and Chi Square test to derive appropriate statistical results to support findings and conclusions based on the primary data collected.

\section{Popularity of brands amongst female riders}

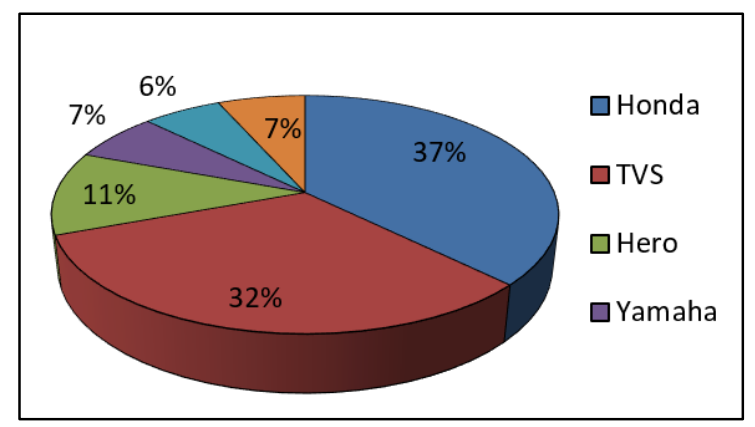

Honda was found to be the most popular brand (37\%) followed by TVS (32\%) and Hero $11 \%$ other brands accounted for $7 \%$.

\section{Use of internet in buying decision}

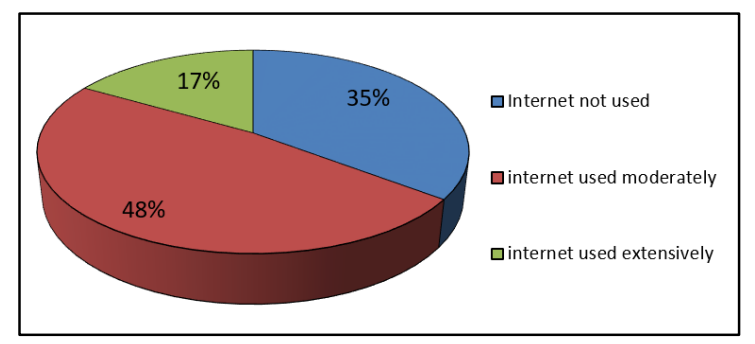

Internet is used extensively or moderately by approximately $65 \%$ of the respondents. 


\section{Awareness of celebrity endorsement}

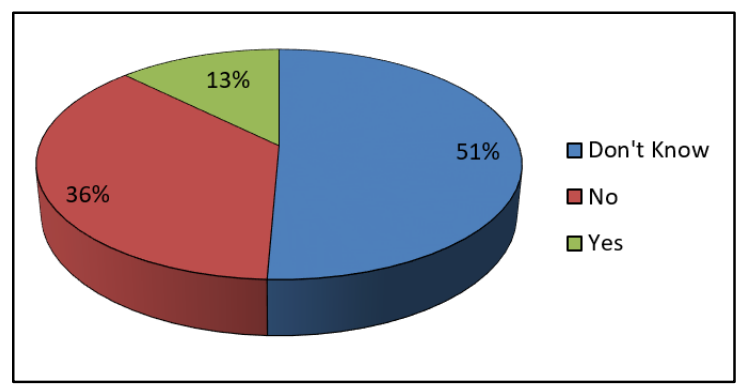

Approximately $51 \%$ of the population did not even know the celebrity who endorsed the brand, and $36 \%$ of the respondents said that the vehicle is not endorsed by any celebrity.

\section{Mode of purchasing the vehicle}

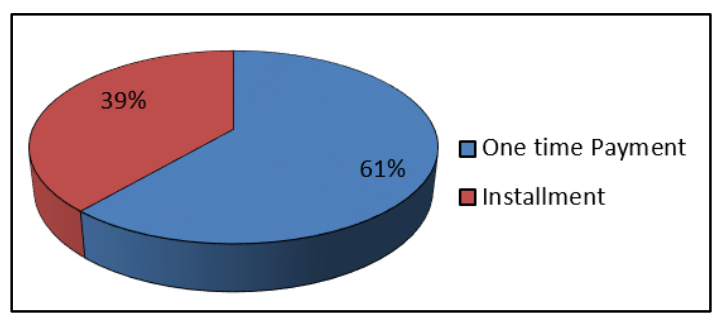

A high number of $61 \%$ of the users purchased the vehicle with one-time payment, only 38.75 of the buyers availed loan facility.

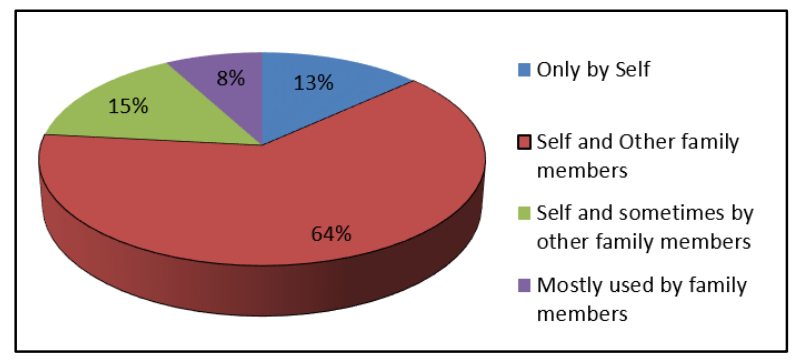

$63 \%$ of the respondents used the vehicle along with other family members, while $15 \%$ respondents said sometimes other family members use their vehicle.

\section{Factors motivating buying decision of female two} wheeler users

There are a number of important factors that motivate women to buy / own a two wheeler. Factors such as necessity, independence, status, easy to use and park, passion and reduced travel expenses have been considered for the study undertaken. The factors are considered based on the assumption that different demographic variables like age, income, educational qualification, occupation, marital status etc. may influence buying decision.

Table 1: Factors that motivate women to buy a two wheeler

\begin{tabular}{|c|c|c|c|c|c|c|c|c|}
\hline & 1 & 2 & 3 & 4 & 5 & 6 & Total & Mean Score \\
\hline \multirow[t]{2}{*}{ Necessity } & 67 & 46 & 14 & 6 & 9 & 8 & 150 & \multirow[t]{2}{*}{4.88} \\
\hline & 402 & 230 & 56 & 18 & 18 & 8 & 732 & \\
\hline \multirow[t]{2}{*}{ Independence } & 16 & 36 & 31 & 47 & 14 & 6 & 150 & \multirow[t]{2}{*}{3.83} \\
\hline & 96 & 180 & 124 & 141 & 28 & 6 & 575 & \\
\hline \multirow[t]{2}{*}{ Status } & 41 & 16 & 11 & 13 & 15 & 54 & 150 & \multirow[t]{2}{*}{3.29} \\
\hline & 246 & 80 & 44 & 39 & 30 & 54 & 493 & \\
\hline \multirow{2}{*}{$\begin{array}{l}\text { Easy to use and } \\
\text { Park }\end{array}$} & 14 & 22 & 29 & 23 & 47 & 15 & 150 & \multirow[t]{2}{*}{3.25} \\
\hline & 84 & 110 & 116 & 69 & 94 & 15 & 488 & \\
\hline \multirow[t]{2}{*}{ Passion } & 3 & 17 & 46 & 26 & 37 & 21 & 150 & \multirow[t]{2}{*}{3.07} \\
\hline & 18 & 85 & 184 & 78 & 74 & 21 & 460 & \\
\hline \multirow{2}{*}{$\begin{array}{ll}\text { Reduce } & \text { travel } \\
\text { expenses } & \\
\end{array}$} & 10 & 13 & 19 & 34 & 28 & 46 & 150 & \multirow[t]{2}{*}{2.7} \\
\hline & 60 & 65 & 76 & 102 & 56 & 46 & 405 & \\
\hline
\end{tabular}

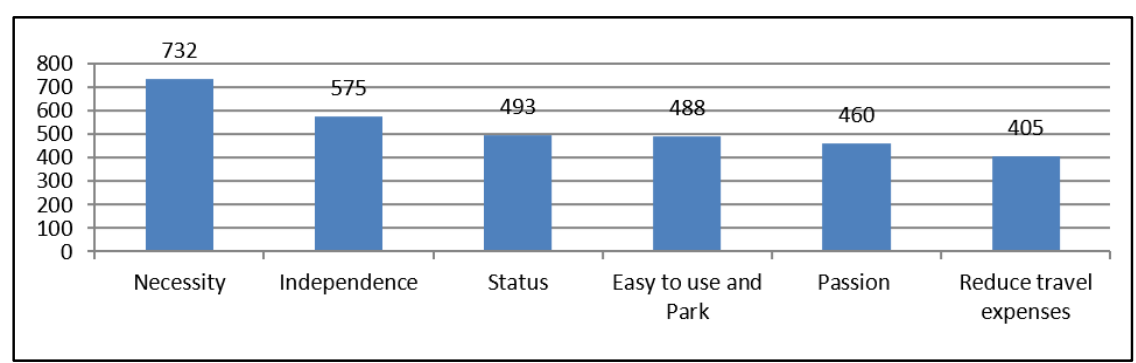

From the above table, it is clear that, Necessity is the most important buying motive (4.88), followed respectively by Independence (3.83), Status (3.29), Easy to use and park (3.25), Passion (3.07) and Reduce travel expenses (2.7). 
Table 2: Chi Square for the Factors affecting buying decision

\begin{tabular}{|l|c|c|c|c|c|c|c|c|c|}
\hline Factors & Score 1 & Score 2 & Score 3 & Score 5 & $\begin{array}{c}\text { Score } \\
\mathbf{6}\end{array}$ & $\begin{array}{c}\text { Observed } \\
\text { freq. }\end{array}$ & Expected & $(\mathbf{O - E})^{\wedge} 2$ & $(\mathbf{O - E})^{\wedge}$ 2/E \\
\hline Necessity & 402 & 230 & 56 & 18 & 8 & 732 & 525.5 & 42642.25 & 81.14605 \\
\hline Independence & 96 & 180 & 124 & 28 & 6 & 575 & 525.5 & 2450.25 & 4.662702 \\
\hline Status & 246 & 80 & 44 & 30 & 54 & 493 & 525.5 & 1056.25 & 2.00999 \\
\hline $\begin{array}{l}\text { Easy to use } \\
\text { and Park }\end{array}$ & 84 & 110 & 116 & 94 & 15 & 488 & 525.5 & 1406.25 & 2.676023 \\
\hline Passion & 18 & 85 & 184 & 74 & 21 & 460 & 525.5 & 4290.25 & 8.164129 \\
\hline $\begin{array}{l}\text { Reduce travel } \\
\text { expenses }\end{array}$ & 60 & 65 & 76 & 56 & 46 & 405 & 525.5 & 14520.25 & 27.6313 \\
\hline & & & & & & 3153 & & $\mathrm{X}^{2}$ & 126.2902 \\
\hline
\end{tabular}

It is observed that necessity is the most important factor for motivating women riders to buy two wheeler in the Palghar area. The Chi square value 126.2902 is significantly high from the table value at $5 \%$ level of significance. The $\mathrm{P}$ value at this level is 0.0001 which shows null hypothesis cannot be accepted. Alternative hypothesis is accepted. Therefore we conclude that necessity aspect is the first preference to buy a two wheeler.

\begin{tabular}{|l|c|c|c|c|}
\hline \multicolumn{6}{|l|}{ Chi square test for Celebrity Endorsement } \\
\hline & $\begin{array}{c}\text { Observed } \\
\text { freq. }\end{array}$ & Expected & $(\mathbf{O - E})^{\wedge} \mathbf{2}$ & $\begin{array}{c}(\mathbf{O}- \\
\mathbf{E})^{\wedge} \mathbf{2} / \mathbf{E}\end{array}$ \\
\hline Don`t Know & 51 & 33.33 & 312.23 & 9.37 \\
\hline No & 36 & 33.33 & 7.13 & 0.21 \\
\hline Yes & 13 & 33.33 & 413.31 & 12.40 \\
\hline & 100 & 99.99 & 732.6667 & 21.9822 \\
\hline
\end{tabular}

1. Approximately $51 \%$ of the population did not even know the celebrity who endorsed the brand, and $36 \%$ of the respondents said that the vehicle is not endorsed by any celebrity.

2. It is observed women riders are not influenced by celebrity endorsement to buy two wheeler in the Palghar area. The Chi square value 21.9822 is significantly high from the table value at $5 \%$ level of significance. The $\mathrm{P}$ value at this level is 0.000017 which shows null hypothesis cannot be accepted. Alternative hypothesis is accepted. Therefore we conclude that celebrity endorsement has no impact on buying behavior a two wheeler as women are not aware about the celebrities who are endorsing it.

\section{Suggestions}

1. Companies need to promote their product strongly on the internet as most users make a strong use of the internet medium to arrive at a buying decision.

2. Most respondents did not even know the celebrity who endorsed their brand, so company could rethink their decision of spending high amounts of money in having a celebrity endorse their brand.

3. Most of the buyers indulged in one-time payment, so perhaps two wheeler loans should be provided at lower interest to encourage buyers to go for loan facility.
4. Most of the women use two-wheeler jointly with other family members, so the positioning of the product should be a family two wheeler.

\section{Conclusion}

Honda was found to be the most popular vehicle, followed by TVS. Most of the users needed the vehicle daily. Utility and the performance of the vehicle are the main aspects which influence consumer behavior with regards to purchase of a two wheeler. Celebrities endorsing a product have little or no impact on the minds of the consumers. A two wheeler purchased is generally used by other members of the family too. A large number of respondents used internet moderately or extensively to gather more information regarding the intended purchase to be made. Most of the respondents brought vehicle through a single down payment instead of going for installment facility.

\section{Limitations of the Study}

1. Due to the current situation of Covid -19, data collection was a major issue.

2. Palghar is a suburb of Mumbai, most of the residents of this suburb use the local trains for commuting and hence the ratio of two wheeler owners and population is low compared to the other parts of the state / country.

3. Respondents were females, and the researcher a male, hence many respondents were reluctant to share information.

4. Some respondents were not very comfortable with technology, so there was difficulty in collecting data through questionnaires in the format of google forms.

\section{Scope Related to Further Studies}

The study leaves a vast scope for more investigation related to buying behavior of two wheeler both from the male and female's perspective, different age groups of users, income groups, geographical locations etc.

\section{Source of Funding}

None.

\section{Conflict of Interest}

The authors declare that there is no conflict of interest regarding the publication of this article. 


\section{References}

1. Gopi R, Angel A. Women's preference towards scooters in Udumalpet. Int J Appl Res. 2017;3(5):94-8.

2. Athulya V, Ramya M. A study on Women's preference towards two wheeler brands with special reference to calicut city. Int J Interdisciplinary Res in Arts Humanit. 2017;2(2):758 .

3. Anandalakshmy A, Brindha K. Women's Preference of Two Wheelers with Special Reference to Coimbatore City. Int $J$ Curr Res Modern Educ. 2017;2(1):79-84.

4. Sakthivel MM, Shanthi RM. Perception of women consumers towards the purchase decision of two wheelers in India - A study with reference to metropolitan cities. Int Res $J$ Business Manag. 2014;2:25-35.

5. Swarna B, Banana K. 2018) A study on customer satisfaction level of two wheeler users in Prakasam (dt), Andhra Pradesh. Int J Res Eng Appl Manag. 2018;4(8):535-44.

6. Rana VP. Consumers Perception towards Two-Wheelers - A Study of Suzuki Access Motor Cycle in Warangal, Telangana. EPRA Int J Econ Business Rev. 2018;6(7).
7. Najeemudeen KP, Panchanatham N. (2016. ) Information Sources for Two-wheeler Purchase: An Analytical Study with Special Focus on Malappuram District of Kerala. Univ J Ind Business Manag 2016;4(2):59-70

8. Nandini VD. A study on customer preference towards two wheelers in Coimbatore city.National Journal of Multidiscip Res Dev. 2018;391):796-8.

9. Thakkar K. Urbanization, rising women users, better roads add speed to two-wheeler sales. The Economic Times.

How to cite this article: Jain A, Joshi N, Mayee AJ. Factors motivating buying behavior of female two wheeler users in the district of Palghar. J Manag Res Anal. 2020;7(4):154-8. 